\title{
EMU ENLARGEMENT, POLICY UNCERTAINTY AND ECONOMIC REFORMS
}

\author{
CARSTEN HEFEKER
}

\author{
CESIFO WORKING PAPER NO. 1767 \\ CATEGORY 6: MONETARY POLICY AND INTERNATIONAL FinANCE \\ JULY 2006 \\ PRESENTED AT CESIFO AREA CONFERENCE ON \\ Macro, Money \& INTERnATIONAL FinANCE, FEBRUARY 2006
}

An electronic version of the paper may be downloaded

- from the SSRN website:

- from the RePEc website:

www.SSRN.com

- from the CESifo website:

www.RePEc.org

www.CESifo-group.de 


\title{
EMU ENLARGEMENT, POLICY UNCERTAINTY AND ECONOMIC REFORMS
}

\begin{abstract}
The paper analyzes the relation between monetary uncertainty and government incentives to implement economic reforms that reduce structural distortions and make economies more flexible. It is shown that uncertainty about the central bank's reaction function leads to more reforms. I relate this result to the debate about central bank setup in a larger monetary union.
\end{abstract}

JEL Code: D72, E52, E58, F33.

Keywords: transparency of monetary policy, ECB voting structure, European Monetary Union, optimal representation, labor market regulation.

\author{
Carsten Hefeker \\ University of Siegen \\ Hoelderlinstr. 3 \\ 57068 Siegen \\ Germany \\ carsten.hefeker@uni-siegen.de
}

July 2006

I thank participants in seminars in Berlin and Munich, especially Helge Berger, Louis Christofides, Bernd Hayo and Ken Kletzer, for helpful comments. 


\section{Introduction}

Faced with the enlargement of the monetary union to new member states, many officials and part of the literature argue that a successful integration of the new members requires their nominal and real convergence to present member states. A monetary union with members too diverse will make the task of the European Central Bank, the ECB, more difficult and member states more vulnerable to shocks because monetary policy cannot react to national idiosyncratic shocks. Therefore, central bankers stress, individual economies must become more flexible in response to economic shocks. ${ }^{1}$ Optimists thus expect that European Monetary Union (EMU) will lead to more flexibility when governments realize the loss of monetary policy as an alternative adjustment instrument. Pessimists do not necessarily expect this to happen and are skeptical concerning in particular the prospects of larger member states in terms of growth and employment. Does monetary union, and particularly its extension to new member states, lead to more or less reforms?

Another issue that is important for the extension of monetary union, and that has raised a lot of attention among policymakers, is the question of how to deal with the new members in the larger ECB council. The council, at present comprising twelve representatives of member states and six representatives of the ECB, is already deemed too large, and it is hard to imagine how 20 or more members should be able to find a consensus in adequate time. Moreover, the extension is likely to make ECB decisions less predictable. Not only a deliberate opaqueness in the communication of the ECB could lead to less “transparency” but the extension of the council is likely to create all kinds to interaction among members that are hard to predict and will thus reduce the predictability of ECB behavior. ${ }^{2}$ The more new

\footnotetext{
${ }^{1}$ This is, of course, the perspective of the optimum currency area literature, looking for alternative adjustment mechanisms when giving up national monetary policy.

2 The concept of transparency used here refers to "preference" uncertainty. For a recent discussion, see Hughes Hallett and Libich (2006).
} 
members there are the more likely it is that uncertainty increases in the present decision making structure.

Based on efficiency and transparency grounds, it has therefore been argued that the ECB's decision structure be transformed upon enlargement. Several proposals have been discussed but the one adopted by the Council of Ministers (against the objection of the European Parliament) is a model that has different groups of countries (ordered by their relative sizes) within which group members rotate. Larger countries will be more often entitled to vote than smaller members. ${ }^{3}$

In this paper, I bring together the aspects of economic reforms and monetary policy with the structure of decision making in the monetary union. I ask whether monetary policy is likely to make countries more or less willing to implement reforms. I distinguish between structural distortions that reduce growth (such as taxation and the presence of monopolies) and measures that increase the flexibility of the economy and its capacity to deal with economic shocks (such as labor and product market regulation). I show that the introduction of a monetary union will tend to have different effects on market flexibility and structural reforms. All governments have an incentive to make their economies more flexible with respect to economic shocks. They realize the common central bank will no longer react as strongly to stabilize economic shocks in the domestic economy as the national central bank did. To counter this effect, economies must become more flexible. This effect is strongest for small economies.

The response of governments to monetary union with respect to structural reforms, however, is very different. Like earlier literature (see next section), I find that governments have, per se, less incentives to reduce structural distortions in a monetary union. This is

\footnotetext{
${ }^{3}$ It is hard to justify this agreement on economic grounds. Criteria for grouping countries should be the similarity of economic structures and not the economic size.
} 
particularly the case for highly distorted large economies. Small economies that are little distorted are induced to implement more reforms. Monetary union is thus likely to lead to a further polarization between more and less distorted economies, making the conduct of monetary policy presumably even more difficult.

However, negative effects can be compensated because uncertainty about the central bank's reaction function increases reforms. Thus, since the extension of the monetary union will, at least initially, create more uncertainty governments may become more reform minded. It also implies that maximizing transparency about the central bank's reaction function is not necessarily good for the economy. There are many reasons for increasing transparency but I show that there is also a case for deliberately keeping the reaction function of the central bank uncertain to some degree.

Because uncertainty about the central bank’s reaction function is presumably a function of the political weights of different countries, the results have implications for the central bank structure. If new members will get only little political weight uncertainty is likely to increase only moderately and vice versa. Highly centralized decision making in the monetary union might therefore have less beneficial consequences than is often argued and the present “one country, one vote” system might not be so bad from the point of view of reforms, even if it is not fully efficient.

The paper is structured as follows. Section 2 relates the present paper to the literature. Section 3 explores the relation between economic reforms and uncertainty for a closed economy. Sections 4 and 5 discuss monetary union, and section 6 concludes.

\section{The Literature}

The paper is related to several strings in the literature. First, I draw on the discussion about economic reforms and monetary union. Calmfors (2001) and Sibert and Sutherland (2000) 
argued that monetary union will lead countries to being less reform willing than under monetary autarchy. The reason is that monetary policy and economic reforms are partial substitutes. The more reforms there are, the higher is output (or the lower is unemployment) and the less reason there is for active monetary policy in order to lower unemployment or increase output. Thus, inflation-averse governments have an incentive to decrease distortionary regulation in order to keep inflation low. In a monetary union the central bank will react less strongly to developments in a single country. The inflationary response to distortions is lower and therefore governments can run a more distionary policy without fearing inflation. Hence, a monetary union reduces governments’ reform willingness. I partially confirm this effect in my model, but point out that this is not necessarily true for countries that join a monetary union with countries that are more distorted than they are themselves. In order to avoid an increase in inflation less distorted countries increase their reforms (Hefeker 2005).

The second literature that I draw on is the huge literature on the influence of monetary policy uncertainty (Brainard 1967, Söderström 2002). However, most of the literature deals with the consequences of uncertainty on the central bank's policy, showing that monetary authorities tend to be more careful if faced with parameter uncertainty, such as the transition of monetary policy. Here, the focus is on how uncertainty about the central bank's behavior will influence domestic agents. This issue has been explored in the literature on central bank transparency (see Eijffinger and Hoeberichts 2000, Winkler 2000, Geraats 2002, Carpenter 2004 for surveys). The question whether transparency is beneficial is usually analyzed in relation with the private sector, where several authors have pointed out that some degree of opaqueness and “creative ambiguity” can be beneficial for the economy (Cukierman and Meltzer 1986). Whereas earlier literature has focused on the influence of uncertainty on wage setters (Sorensen 1991, Grüner 2002), I analyze how governments react to such uncertainty. 
More uncertainty makes governments more careful and leads them to reduce structural distortions and to make the economy more flexible.

The third string that I relate to is the literature on the design of the common central bank which mainly deals with efficiency issues and the need to reform the ECB council because of the large number of members (Baldwin et al. 2002, Berger 2002, Meade and Sheets 2002, Ullrich 2004). Most of these authors argue that because of efficiency considerations it is highly unlikely that an even larger ECB council will be able to make efficient and speedy policy decisions. Moreover, it is often argued that it can be expected that national representatives vote with a national perspectives. This implies that new member states will distort the ECB's decision, given that many of these countries are economically small but politically overrepresented (Berger 2004). Therefore, they might unduly influence the common central bank’s policy and lead to an inefficient policy from a European wide perspective. I argue below that there could also be a positive effect if such an enlargement is creating more uncertainty. ${ }^{4}$

\section{Policy Choices in the Closed Economy}

\subsection{The Model}

This section develops the underlying model and describes the interaction between a domestic government and a national central bank. Against this benchmark the case of monetary union will be compared. The following model is on Sibert and Sutherland (2001).

Output $y_{i}$ is a positive function of surprise inflation $\pi_{\mathrm{i}}-\pi_{\mathrm{i}}^{\mathrm{e}}$ where $\pi_{\mathrm{i}}^{\mathrm{e}}$ is the subjective expected rate of inflation of the private sector. Output is decreasing in structural distortions $\tau_{\mathrm{i}}$, such as distortionary taxation, the presence of monopolies, tariff protection, the impact of

\footnotetext{
${ }^{4}$ Another positive effect of a larger decision making body could be that more information is processed, thus allowing for better decisions (for a survey of these arguments, see Gerling et al. 2005).
} 
labor unions, and other uncompetitive structures in the economy that push output below the natural level $\mathrm{y}_{\mathrm{i}}^{\mathrm{n}} \cdot{ }^{5}$ Moreover, the economy may be hit by exogenous shocks $\varepsilon_{\mathrm{i}}$, with $\varepsilon_{\mathrm{i}} \sim \mathrm{N}\left(0, \sigma_{\varepsilon}^{2}\right)$, whose effect on output is given as $\mathrm{g}_{\mathrm{i}}=\gamma_{\mathrm{i}} \varepsilon_{\mathrm{i}}$. Making the economy more flexible by reducing labor and product market regulation can help the economy to adjust more quickly and thus cushion part of the shock. ${ }^{6}$ The lower the level of such regulations $\gamma_{i}$, the lower will be the impact of exogenous developments and shocks. We hence have

$$
\mathrm{y}_{\mathrm{i}}=\mathrm{y}_{\mathrm{i}}^{\mathrm{n}}+\left(\pi_{\mathrm{i}}-\pi_{\mathrm{i}}^{\mathrm{e}}\right)-\tau_{\mathrm{i}}-\mathrm{g}_{\mathrm{i}}
$$

Clearly, the first best situation would be reached if $\gamma_{\mathrm{i}}$ and $\tau_{\mathrm{i}}$ could be reduced to zero. However, it is assumed that the economy is starting out with given levels of distortions, $\bar{\gamma}_{\mathrm{i}}$ and $\bar{\tau}_{\mathrm{i}}$ and that deregulation is politically costly for the government. Abolishing labor market regulation might lead to protests, reducing structural distortions might prompt firms to threat a loss of jobs, and the reduction of taxes might imply the government is no longer able to finance pet projects. More regulation instead might lead to protests by employers and scare away foreign investors. Therefore, any changes to the given level of $\bar{\gamma}_{\mathrm{i}}$ and $\bar{\tau}_{\mathrm{i}}$ risk to alienate one or several interest groups. The political costs are increasing in deviations of $\gamma_{i}$ and $\tau_{i}$ from $\bar{\gamma}_{i}$ and $\bar{\tau}_{i}$; they are assumed as $C_{i}^{\tau}=\phi_{\tau}\left(\tau_{i}-\bar{\tau}_{i}\right)^{2}$ and $C_{i}^{\gamma}=\phi_{\gamma}\left(\gamma_{i}-\bar{\gamma}_{i}\right)^{2}$. The relative loss of government from these policy measures are given as $\phi_{\gamma}$ and $\phi_{\tau}$ respectively. For simplicity, I assume that utility parameters are equal for all governments. This is not necessarily a very

\footnotetext{
${ }^{5} \tau_{\mathrm{i}}$ should be thought of as a vector of different policy measures and not one single policy. ${ }^{6}$ On the possible relations between the two types of reforms, see Berger and Danninger (2005).
} 
realistic assumption but helps to focus on the economics of the model by abstracting from the influence of preferences.

Apart from wishing to minimize the political costs of reforms, the government aims to keep inflation close to zero and to avoid deviations of output from the distortion free level. Its loss function is

$$
E\left[L_{i}\right]=E\left[\pi_{i}^{2}+\lambda\left(y_{i}-y_{i}^{n}\right)^{2}+C_{i}^{\tau}+C_{i}^{\gamma}\right]
$$

The objective function of the monetary authority is akin to the government's preferences but without the losses stemming from economic reform. Independent central banks are not elected into office, much less exposed to public resistance against policies and unlikely to be made responsible for economic reforms. Thus, the central bank is only concerned with the output gap and inflation. Another difference is that the preference parameter $\lambda_{i}$ of the national central bank might be different from those of the government. The national monetary authority minimizes

$$
\mathrm{V}_{\mathrm{i}}=\pi_{\mathrm{i}}^{2}+\lambda_{\mathrm{i}}\left(\mathrm{y}_{\mathrm{i}}-\mathrm{y}_{\mathrm{i}}^{\mathrm{n}}\right)^{2}
$$

I assume that the central bank sets its policy when possible uncertainties have been resolved. This reflects the standard timing in this type of model, where it is assumed that the central bank sets its policy after stochastic shocks have realized, but where government and private sector react before uncertainties have been dissolved. The formal time structure is thus given as: (i) the government sets the levels of regulation $\gamma_{i}$ and $\tau_{i}$, (ii) the private sector forms its expectations about inflation $\pi_{\mathrm{i}}^{\mathrm{e}}$ based on the policy choices of the government, (iii) 
the shock $\varepsilon_{\mathrm{i}}$ is realized, (iv) the central bank sets inflation $\pi_{\mathrm{i}}$. The game structure is Stackelberg. The government is the Stackelberg leader taking into account how the central bank is likely to react to its policy choices. The private sector plays Nash against the government and the central bank. This reflects the idea that monetary policy follows after reform policies have been determined and that monetary policy can (to some degree) be foreseen by the government.

\subsection{Uncertainty and Reforms}

The model is solved by backward induction. The central bank's reaction is derived first.

Optimization of the monetary authority's loss function with respect to inflation yields:

$$
\pi_{\mathrm{i}}=\theta_{\mathrm{i}}\left(\pi_{\mathrm{i}}^{\mathrm{e}}+\tau_{\mathrm{i}}+\gamma_{\mathrm{i}} \varepsilon_{\mathrm{i}}\right)
$$

$\theta_{\mathrm{i}}=\lambda_{\mathrm{i}} /\left(1+\lambda_{\mathrm{i}}\right)$ is the reaction parameter of the central bank which is obviously increasing in the relative weight it puts on stabilizing output $\lambda_{\mathrm{i}}$. Depending on the transparency of a single central bank, and especially if the central bank is run by a collegiate body, it could be that the central bank's reaction is not perfectly predictable by the private sector. The private sector will certainly form expectations about how the central bank reacts to economic developments, such as commodity price shocks, fiscal policy changes or wages, but the central bank's reaction will, in general, not be perfectly predictable. ${ }^{7}$ This uncertainty is likely to be larger the larger is the governing body and if new persons enter the central bank's decision making structure. The extension of the monetary union is a case where the central

\footnotetext{
${ }^{7}$ In fact, the standard assumption that the central bank's reaction can be predicted accurately might be a less realistic case than the assumption that there is some noise in the central bank's reaction.
} 
bank's reaction function will be more uncertain than it is before enlargement. In terms of the model, this is represented by the fact that $\theta_{\mathrm{i}}$ can be stochastic. I assume $\theta_{\mathrm{i}} \sim \mathrm{N}\left(\theta, \sigma_{\theta}^{2}\right)$ if $\theta_{\mathrm{i}}$ is stochastic and hence $\sigma_{\theta}^{2}=0$ for a fully predictable central bank. ${ }^{8}$

Since government and private sector determine their action simultaneously, I consider next the government. The government optimizes its structural reforms and the ability of the economy to digest shocks by taking the expected reaction of the central bank into account.

The level of structural distortions remaining after reforms is

$$
\tau_{\mathrm{i}}=\frac{\phi_{\tau} \bar{\tau}_{\mathrm{i}}-\left(\lambda(1-\theta)^{2}+\Theta\right) \pi_{\mathrm{i}}^{\mathrm{e}}}{\phi_{\tau}+\left(\lambda(1-\theta)^{2}+\Theta\right)},
$$

where $\Theta=\theta^{2}+(1+\lambda) \sigma_{\theta}^{2}$ with $E\left[\lambda_{i}\right]=\lambda$ and $E\left[\theta_{i}\right]=\theta$.

The level of distortions set by the government is obviously higher the higher are initial distortions $\bar{\tau}_{\mathrm{i}}$ and government aversion to reforms $\phi_{\tau}$. It is decreasing in expected inflation because expected inflation pushes up actual inflation. In order to keep inflation to a moderate level, the government reacts to higher expected inflation with more reforms. The more uncertain is the reaction of the central bank (captured by $\Theta$ ), the more cautious is the government and the more reforms are implemented.

The amount of rigidity, remaining after reforms, is given as

\footnotetext{
${ }^{8}$ Thus uncertainty refers to the central bank's preferences, as in Canzoneri (1985) and Cukierman and Meltzer (1986). An alternative way to model non-transparency is a nonobservable employment target or control errors (see Faust and Svensson 2001, 2002, Jensen 2002).
} 


$$
\gamma_{\mathrm{i}}=\frac{\phi_{\gamma} \bar{\gamma}_{\mathrm{i}}}{\phi_{\gamma}+\left(\lambda(1-\theta)^{2}+\Theta\right) \sigma_{\varepsilon}^{2}} .
$$

It is increasing in the initial level of rigidity $\bar{\gamma}_{\mathrm{i}}$ and the aversion against flexibility $\phi_{\gamma}$ and decreasing in the variability of the economic shock $\varepsilon_{\mathrm{i}}$, reflecting the fact that the government will make the economy more flexible if the variability of economic shocks is high. The uncertainty about the central bank’s reaction and the variability of economic shocks reinforce each other.

Assuming rational expectations, the expectations of the private sector are

$$
\pi_{\mathrm{i}}^{\mathrm{e}}=\mathrm{E}\left[\pi_{\mathrm{i}}\right]=\frac{\theta \phi_{\tau} \bar{\tau}_{\mathrm{i}}}{(1-\theta) \phi_{\tau}+\left(\lambda(1-\theta)^{2}+\Theta\right)}
$$

In contrast to the standard argument that expected inflation is falling in the central bank’s transparency (van der Cruijsen and Demertzis 2005), I find that expected inflation is decreasing in uncertainty. The simple reason is that uncertainty is reform increasing which leads the private to expect a less active monetary policy.

With these expectations, the amount of structural reforms in equilibrium is

$$
\tau_{\mathrm{i}}=\frac{(1-\theta) \phi_{\tau} \bar{\tau}_{\mathrm{i}}}{(1-\theta) \phi_{\tau}+\left(\lambda(1-\theta)^{2}+\Theta\right)} .
$$

Both types of distortions are thus decreasing in the amount of uncertainty about the central bank's reaction parameter to economic developments. The higher is the uncertainty the more the government will attempt to make the economy less vulnerable to shocks and to lower structural distortions in the economy. Thus, uncertainty is beneficial for inflation and 
output because the government's action have a direct positive impact on economic

performance and an improvement in the economic performance reduces incentives to use monetary policy to boost output. Moreover, a more flexible economy requires less active monetary policy in response to shocks.

The rate of inflation will therefore result as

$$
\pi_{\mathrm{i}}=\theta_{\mathrm{i}}\left(\frac{\phi_{\tau} \bar{\tau}_{\mathrm{i}}}{(1-\theta) \phi_{\tau}+\left(\lambda(1-\theta)^{2}+\Theta\right)}+\frac{\phi_{\gamma} \bar{\gamma}_{\mathrm{i}}}{\phi_{\gamma}+\left(\lambda(1-\theta)^{2}+\Theta\right) \sigma_{\varepsilon}^{2}} \varepsilon_{\mathrm{i}}\right) .
$$

\section{Policy Choices in the Monetary Union}

Having established the case of a single economy and the interaction between uncertainty and economic reforms, the question is how this is transformed in a monetary union. As argued above, uncertainty concerning the reaction function of the central bank is arguably more relevant in the case of the EMU, and particular so with the prospect of enlargement. There are at present 12 national representatives of member states and a board comprising additional six members. Extending this body to additional members will make decision making in the EMU more cumbersome and presumably less predictable than today. ${ }^{9}$ Extension means that new members will be added whose preferences are mostly unknown and who might shift the policy stance of the ECB. The interaction of a larger group of individuals in collective decision making might lead to an outcome that is different from what the smaller ECB council had decided. ${ }^{10}$ Especially in the initial years it is thus likely that the larger central

\footnotetext{
${ }^{9}$ Ten new members joined the union in May 2004, of which seven have already joined the ERM II (a pre-entry qualification for EMU membership). Slovenia is scheduled to become the first new member of EMU by January 2007 and others will follow shortly afterwards.

${ }^{10}$ Goldberg and Klein (2005) show that the perception of the ECB's reaction parameter has changed over time as markets developed a view of the ECB's characteristics and the relative weight it assigns to different objectives.
} 
bank council will create more uncertainty than before. Given that markets need some time to assess the preferences of policymakers (which has also happened with the initial group of monetary policymakers in the ECB, see Goldberg and Klein 2005), they might expect new members will bring different preferences to the ECB board. Even if markets expect that new members have similar preferences to older members, $\mathrm{E}\left[\lambda_{2}\right]=\lambda_{1}=\lambda$, there might be some variance around this expected value at least for an initial period.

Moreover, it is likely that uncertainty will be larger if the voting power of the new members is large. First, the larger the relative size of the newcomers in respect to the older members, the higher their relative influence. This is obvious if monetary policy is a weighted average of individually preferred policies, but also if monetary policy is determined by the median voter, different preferences of newcomers shift the median’s position (Hefeker 2003). Finally, even if monetary policy is set by consensus, as the ECB claims it is, new members will have more influence the larger is their group. Therefore the amount of uncertainty created is arguably a positive function of the relative voting weight of the new members. ${ }^{11}$

To keep matters simple, I consider a monetary union built of two countries only. Let country 1 represent the current members of the EMU and country 2 represent the new members. I assume $\mathrm{s}_{1}+\mathrm{s}_{2}=1$ and $\mathrm{z}_{1}+\mathrm{z}_{2}=1$ where $\mathrm{s}_{\mathrm{i}}$ is the relative economic weight of the two regions and $z_{i}$ is their relative political weight. Since it is possible that the newer members receive a larger political weight in the ECB council than they have in economic terms, $\mathrm{z}_{2}>\mathrm{s}_{2}$, I allow political and economic weights to differ. In fact, if the present "one country, one vote” principle is extended to the new members they would be significantly over-represented politically (Berger 2002). Even if the proposed changes to the voting structure ECB are implemented (see Ullrich 2004), which would lead to some reduction in the

\footnotetext{
${ }^{11}$ Fatum (2006) instead argues that any ECB council is likely to adopt the preferred position of the most conservative member and will thus reflect the Bundesbank's preferred policy.
} 
political power of the smaller members, they will continue to have more political than economic weight. But even if the ECB monetary policy would be completely centralized, a political weight of zero would not imply an economic weight of zero. Even if new members do not have a say in the monetary policy, developments in those regions will be taken into account with the relative weight $\mathrm{s}_{2} \cdot 12$

The objective function of the larger central bank is therefore

$$
\mathrm{V}^{\mathrm{MU}}=\left(\mathrm{s}_{1} \pi_{1}+\mathrm{s}_{2} \pi_{2}\right)+\left(\mathrm{z}_{1} \lambda_{1}+\mathrm{z}_{2} \lambda_{2}\right)\left[\mathrm{s}_{1}\left(\mathrm{y}_{1}-\mathrm{y}_{1}^{\mathrm{n}}\right)+\mathrm{s}_{2}\left(\mathrm{y}_{2}-\mathrm{y}_{2}^{\mathrm{n}}\right)\right]^{2}
$$

The ECB's policy follows from optimizing (9) as

$$
\pi=\hat{\theta}\left(\pi^{\mathrm{e}}+\mathrm{s}_{1} \tau_{1}+\mathrm{s}_{2} \tau_{2}+\mathrm{s}_{1} \gamma_{1} \varepsilon_{1}+\mathrm{s}_{2} \gamma_{2} \varepsilon_{2}\right)
$$

where $\hat{\theta}=z_{1} \theta_{1}+z_{2} \theta_{2}$ and $E[\hat{\theta}]=\theta$. The rate of inflation is equal in both regions and I hence abstract from asymmetric developments in the rate of inflation due, for instance, to the influence of the Balassa-Samuelson effect. Therefore, expected inflation is also the same in both regions. To keep matters simple, I also assume $\operatorname{Cov}\left(\varepsilon_{1}, \varepsilon_{2}\right)=0$ and equal variance of shocks in the two regions of the monetary union.

The common central bank reacts to developments in any single member state according to its economic weight, thus neglecting asymmetric national developments or differences in the transmission of monetary policy (Benigno 2004). Developments in larger countries will hence be taken more into account than developments in smaller countries. This applies to

\footnotetext{
${ }^{12}$ The assumption is hence that the ECB council members have a European and not national perspective.
} 
structural distortions, $\tau_{\mathrm{i}}$, as well as to shocks $\varepsilon_{\mathrm{i}}$ and to the economies' flexibility in reaction to shocks $\gamma_{\mathrm{i}}$.

Although there is a now a common central bank, I assume that governments’ policies remain uncoordinated and that the national governments decide about their reform efforts without consulting other governments. This is an adequate assumption for the European Monetary Union as of now, despite some tentative attempts by the Commission to coordinate member states’ policies in the framework of the Lisbon objectives and the Broad Economic Policy Guidelines.

Following the same steps as above, structural distortions and flexibility after reforms are

$$
\begin{array}{r}
\tau_{\mathrm{i}}=\phi_{\tau} \cdot \frac{\bar{\tau}_{\mathrm{i}}\left[(1-\theta)\left(\phi_{\tau}+\lambda\left(1-\mathrm{s}_{\mathrm{j}} \theta\right)\right)+\mathrm{s}_{\mathrm{i}}^{2} \Theta\right]-\mathrm{s}_{\mathrm{j}} \mathrm{s}_{\mathrm{i}} \Theta \bar{\tau}_{\mathrm{j}}}{(1-\theta)\left(\phi_{\tau}+\lambda\left(1-\mathrm{s}_{\mathrm{j}} \theta\right)\right)\left(\phi_{\tau}+\lambda\left(1-\mathrm{s}_{\mathrm{i}} \theta\right)\right)+\Theta\left[\mathrm{s}_{\mathrm{i}}^{2}\left(\phi_{\tau}+\lambda\left(1-\mathrm{s}_{\mathrm{j}} \theta\right)\right)+\mathrm{s}_{\mathrm{j}}^{2}\left(\phi_{\tau}+\lambda\left(1-\mathrm{s}_{\mathrm{i}} \theta\right)\right)\right]} \\
\quad \mathrm{i}, \mathrm{j}=1,2, \mathrm{i} \neq \mathrm{j}, \\
\gamma_{\mathrm{i}}=\frac{\phi_{\gamma} \bar{\gamma}_{\mathrm{i}}}{\phi_{\gamma}+\left(\lambda\left(1-\mathrm{s}_{\mathrm{i}} \theta\right)^{2}+\mathrm{s}_{\mathrm{i}}^{2} \Theta\right) \sigma_{\varepsilon}^{2}} \quad \mathrm{i}, \mathrm{j}=1,2, \mathrm{i} \neq \mathrm{j},
\end{array}
$$

where $\lambda\left(1-\mathrm{s}_{\mathrm{i}} \theta\right)>\lambda(1-\theta)$ for all $\mathrm{s}_{\mathrm{i}}<1$.

Like in the case of monetary autonomy, flexibility is determined through the initial degree of distortions, the aversion to reforms, the variability of economic shocks and the variability of the central bank's reaction function. As before, it follows that shocks and uncertainty are both reform inducing. Because of the assumption that shocks are uncorrelated, flexibility is only affected by the national degree of distortions and independent of those in the other country. 
The case of structural distortions is more complicated. First, structural reforms are strategic substitutes. The higher the initial distortions in the other country, the more incentives there are for the government to lower its own distortions. In order to avoid that the higher distortions in the other country create too much inflation, the domestic government has an incentive to implement more reforms itself. As before, the initial level of structural distortions in the home country, $\bar{\tau}_{\mathrm{i}}$ increases the level of distortions after reforms. Second, the influence of uncertainty is not obvious but it can be shown that $\frac{\partial \tau_{i}}{\partial \sigma_{\theta}^{2}}<0$. That is, distortions will decrease with monetary uncertainty.

The rate of inflation in EMU follows as

$$
\begin{aligned}
& \pi=\hat{\theta} \cdot \frac{\phi_{\tau}\left[\left(\phi_{\tau}+\lambda\left(1-\mathrm{s}_{1} \theta\right)\right) \mathrm{s}_{1} \bar{\tau}_{1}+\left(\phi_{\tau}+\lambda\left(1-\mathrm{s}_{2} \theta\right)\right) \mathrm{s}_{2} \bar{\tau}_{2}\right]}{(1-\theta)\left(\phi_{\tau}+\lambda\left(1-\mathrm{s}_{1} \theta\right)\right)\left(\phi_{\tau}+\lambda\left(1-\mathrm{s}_{2} \theta\right)\right)+\Theta\left[\mathrm{s}_{1}^{2}\left(\phi_{\tau}+\lambda\left(1-\mathrm{s}_{2} \theta\right)\right)+\mathrm{s}_{2}^{2}\left(\phi_{\tau}+\lambda\left(1-\mathrm{s}_{1} \theta\right)\right)\right]} \\
& +\hat{\theta} \cdot\left[\mathrm{s}_{1} \frac{\phi_{\gamma} \bar{\gamma}_{1}}{\phi_{\gamma}+\left(\lambda\left(1-\mathrm{s}_{1} \theta\right)^{2}+\mathrm{s}_{1}^{2} \Theta\right) \sigma_{\varepsilon}^{2}} \varepsilon_{1}+\mathrm{s}_{2} \frac{\phi_{\gamma} \bar{\gamma}_{2}}{\phi_{\gamma}+\left(\lambda\left(1-\mathrm{s}_{2} \theta\right)^{2}+\mathrm{s}_{2}^{2} \Theta\right) \sigma_{\varepsilon}^{2}} \varepsilon_{2}\right] .
\end{aligned}
$$

It is a function of the relative weights of the two countries and depends on whether their flexibility and structural distortions will increase or decrease (which is considered in the next section). Expected inflation, however, is only a question of initial structural distortions and can thus readily be compared to the expected inflation in each country before monetary union. $\mathrm{E}\left[\pi_{\mathrm{i}}^{\mathrm{N}}\right]>\mathrm{E}\left[\pi^{\mathrm{MU}}\right]$, where the superscripts $\mathrm{N}$ and MU refer to monetary autonomy and monetary union respectively, requires that

$$
\begin{aligned}
& \bar{\tau}_{\mathrm{i}}\left(\phi_{\tau}+\lambda\right)\left[(1-\theta)\left(\phi_{\tau}+\lambda\left(1-\mathrm{s}_{\mathrm{j}} \theta\right)\right)+\Theta\left(\mathrm{s}_{\mathrm{j}}-\mathrm{s}_{\mathrm{i}}\right)\right]> \\
& \bar{\tau}_{\mathrm{j}}\left[(1-\theta)\left(\phi_{\tau}+\lambda(1-\theta)\right)+\Theta\right]\left(\phi_{\tau}+\lambda\left(1-\mathrm{s}_{\mathrm{i}} \theta\right)\right) .
\end{aligned}
$$


Thus, a single country can expect a fall in the rate of inflation if it enters a monetary union with a country that is sufficiently less distorted than the country itself. In this case, monetary discipline is imported because the lower distortions in that country lead the common central bank to run a less inflationary policy than the national central bank did because of these structural distortions. The positive effect of reducing inflation is increasing in the relative economic size of the less distorted country $s_{j}>s_{i}$.

\section{The Influence of Monetary Union on Reforms}

As I have argued above, the case of uncertainty is most relevant for the monetary union because in the initial years after enlargement, a larger policy making organ is likely to create more uncertainty. I will hence assume that uncertainty under national autonomy is zero $\gamma_{i}^{N} \mid \sigma_{\theta}^{2}=0$ whereas it is positive in the monetary union $\gamma_{i}^{M U} \mid \sigma_{\theta}^{2}>0$.

From (5) and (12), the condition that EMU leads to more flexibility, $\gamma_{i}^{\mathrm{N}}>\gamma_{i}^{\mathrm{MU}}$, is

$$
\mathrm{s}_{\mathrm{i}}^{2}\left(\theta^{2}+\sigma_{\theta}^{2}\right)>\theta^{2}\left(\mathrm{~s}_{\mathrm{i}}-\mathrm{s}_{\mathrm{j}}\right),
$$

and it is always fulfilled. Even if setting $\sigma_{\theta}^{2}=0$ the condition simplifies to $\theta^{2} s_{j}\left(1-s_{i}\right)>0$ by making use of the fact that $s_{i}+s_{j}=1$. Naturally, only if $s_{i}=1$ it follows that $\gamma_{i}^{N}=\gamma_{i}^{M U}$.

The creation of a monetary union leads countries to implement measures to become more flexible and increase their ability to cope with economic shocks. This incentive is increased if monetary union leads to more uncertainty concerning the reaction of the common central bank. However, even if this is not the case, countries have an incentive to become more flexible because they realize the common central bank will care less for idiosyncratic 
shocks that hit single countries. Therefore, the only alternative instrument to cope with such shocks is to make the economy more flexible and less vulnerable to such shocks. Monetary union serves as an engine for more reforms.

Next, I compare the levels of structural distortion under monetary union $\tau_{\mathrm{i}}^{\mathrm{MU}} \mid \sigma_{\theta}^{2}>0$ and under monetary autonomy $\tau_{\mathrm{i}}^{\mathrm{N}} \mid \sigma_{\theta}^{2}=0$. From (7) and (11), one finds that EMU leads to a reduction in structural distortions, $\tau_{\mathrm{i}}^{\mathrm{N}}>\tau_{\mathrm{i}}^{\mathrm{MU}}$, if

$$
\begin{aligned}
& \theta^{2} \mathrm{~s}_{\mathrm{i}} \mathrm{s}_{\mathrm{j}}\left[(1-\theta)\left(\phi_{\tau}+\lambda(1-\mathrm{s} \theta)\right)\left(\bar{\tau}_{\mathrm{j}}-\bar{\tau}_{\mathrm{i}}\right)+\theta^{2}\left(\bar{\tau}_{\mathrm{j}}-\mathrm{s}_{\mathrm{i}} \bar{\tau}_{\mathrm{i}}\right)\right] \\
& +(1+\lambda) \sigma_{\theta}^{2}\left[\mathrm{~s}_{\mathrm{i}}(1-\theta)\left(\phi_{\tau}+\lambda\left(1-\mathrm{s}_{\mathrm{j}} \theta\right)\right)\left(\mathrm{s}_{\mathrm{i}} \bar{\tau}_{\mathrm{i}}+\mathrm{s}_{\mathrm{j}} \bar{\tau}_{\mathrm{j}}\right)+\mathrm{s}_{\mathrm{i}} \mathrm{s}_{\mathrm{j}} \theta^{2}\left(\bar{\tau}_{\mathrm{j}}-\mathrm{s}_{\mathrm{i}} \bar{\tau}_{\mathrm{i}}\right)\right]>0 .
\end{aligned}
$$

I analyze the condition in parts. For the case without uncertainty (so that $\sigma_{\theta}^{2}=0$ ) it is possible to show the condition is only fulfilled if $\bar{\tau}_{\mathrm{j}}>\bar{\tau}_{\mathrm{i}}$. That is, countries will reduce their distortions if they lower distortions than their partners in the monetary union while countries that are more distorted experience a further deterioration of their structural distortions. Hence, some countries will experience an increase in structural distortions while others see their distortions fall. Since the second part of the condition (multiplied by $\sigma_{\theta}^{2}$ ) is always positive it follows that uncertainty can, at least partially, compensate for the negative effect of $\bar{\tau}_{\mathrm{j}}<\bar{\tau}_{\mathrm{i}}$. A high enough degree of uncertainty is an incentive for all countries to implement more structural reforms, even for those that would not implement them without uncertainty.

The intuition of the result is straightforward. As has been shown in the earlier literature, for instance by Calmfors (2001) and Sibert and Sutherland (2000), if structural reforms and monetary policy are considered as substitutes by the government, and if the government is a Stackelberg leader with respect to the central bank, governments implement structural reforms 
to reduce inflationary pressure that arises because the central bank uses monetary policy to lower structural unemployment (which is, of course, in vain—reflecting the standard inflation bias (Barro and Gordon 1983)). Because a monetary union implies that the central bank will no longer react as strongly to distortions in the home country as the national central bank before monetary union, inflationary pressure automatically declines and this prompts the reform-averse government to reduce its reform efforts.

Hefeker (2005) has demonstrated that this result can be turned around if the assumption of symmetric countries is given up. Countries that are more distorted will reduce their reform efforts, as demonstrated in the earlier literature, but the less distorted countries fear the “import” of inflation and are more concerned to reduce this pressure by implementing even more reforms. Hence, asymmetric monetary unions are likely to see a further polarization of structural unemployment in the monetary union.

This negative consequence for some of the members of the larger EMU, however, can be avoided if the common central bank is less open and transparent than national central banks. By deliberately creating uncertainty about its reaction function, structural distortions can be reduced even in countries that are relatively more distorted. While it certainly not easy to deliberately create uncertainty, the conclusion at least is that maximum transparency in the larger central bank could have negative effects for those member countries that enter monetary union relatively more distorted.

\section{Conclusion}

The paper has demonstrated the beneficial, that is, reform inducing effects of uncertainty about the central bank's reaction function. While this does not invalidate the general positive effects of central bank transparency, clear policy decision and communication about them, the paper stresses that there can also be positive effects of preference uncertainty. In a closed 
economy, uncertainty leads governments to implement more structural reforms and to try to make the economy less vulnerable to economic shocks.

In the case of monetary union, it follows that all governments have an incentive to make their economies more flexible in order to be able to compensate for less stabilizing influence of the central bank. Since the central bank will react the least to the smallest economies their incentives to become more flexible in a monetary union are largest. This would predict that the new member states of the EMU will be more flexible in the monetary union than the larger (and older) member states. This might be one possible explanation (among others) why in general smaller economies are more flexible than larger ones, and why the difference in these matters between larger and smaller economies has further increased since the start of EMU.

The probability that monetary union will also lead to a reduction in structural distortions in member countries is less uniform. Only those countries that have relatively low distortions will reduce their distortions further, whereas those that have levels of distortions are likely to undertake less efforts to lower them. Monetary union, according to this model, will hence lead to a further polarization of high and low distortion countries. However, the uncertainty created by the introduction (or extension) of monetary union can potentially counteract this negative influence for high distortion countries.

This has also implications for the relative weights that countries should have in a monetary union. If increasing the relative weight of newcomers will lead to more uncertainty about the reaction of the central bank than this is something that should not necessarily be avoided. There is hence some justification for the "one country, one vote" principle that the ECB applies to its decision making structure. A full centralization, as has been advocated by some observers, could be less beneficial than is often claimed even if leading to more efficient decision making. If having more members in the decision making process increases 
uncertainty, this ambiguity need not only have negative consequences. Deriving the optimal amount of uncertainty, however, would require having a fuller model that also incorporates the positive effects of lower uncertainty and transparency.

\section{References}

Baldwin, Richard, Erik Berglöf, Francesco Giavazzi and Mika Widgrén (2000) EU Reforms for Tomorrow’s Europe, CEPR-Discussion Paper 2623.

Barro, Robert and David Gordon (1983) A Positive Theory of Monetary Policy in a Natural Rate Model, Journal of Political Economy 91, 589-610.

Benigno, Pierpaolo (2004) Optimal Monetary Policy in a Currency Area, Journal of International Economics 63, 293-320.

Berger, Helge (2002) The ECB and Euro-Area Enlargement, IMF-Working Paper 02/175.

Berger, Helge and Stephan Danninger (2005) Labor and Product Market Deregulation: Partial, Sequential, or Simultaneous Reform?, IMF-Working Paper 05/227.

Brainard, William (1967) Uncertainty and the Effectiveness of Policy, American Economic Review 57, 411-425.

Calmfors, Lars (2001) Labor Market Reform and Monetary Union, Journal of Labor Economics 19, 265-289.

Canzoneri, Matthew (1985) Monetary Policy Games and the Role of Private Information, American Economic Review 75, 1056-1070.

Carpenter, Seth (2004) Transparency and Monetary Policy: What Does the Academic Literature Tell Policymakers?, Board of Governors of the Federal Reserve System, mimeo.

Cukierman, Alex and Alan Meltzer (1986) A Theory of Ambiguity, Credibility and Independence under Discretion and Asymmetric Information, Econometrica 54, 10991128.

Eijffinger, Sylvester and Marco Hoeberichts (2000) Central Bank Accountability and Transparency: Theory and Some Evidence, Bundesbank Discussion Paper 06/00.

Fatum, Rasmus (2006) One Monetary Policy and 18 Central Bankers: The European Monetary Policy as a Game of Strategic Delegation, Journal of Monetary Economics 53, 659-669.

Faust, Jon and Lars Svensson (2001) Transparency and Credibility: Monetary Policy with Unobservable Goals, International Economic Review 42, 369-397. 
Faust, Jon and Lars Svensson (2002) The Equilibrium Degree of Transparency and Control in Monetary Policy, Journal of Money, Credit and Banking 34, 520-539.

Geraats, Petra (2002) Central Bank Transparency, Economic Journal 112, F 532-565.

Gerling, Kerstin, Hans Peter Grüner, Alexandra Kiel and Elisabeth Schulte (2005) Information Acquisition and Decision Making in Committees: A Survey, European Journal of Political Economy 21, 563-597.

Goldberg, Linda and Michael Klein (2005) Establishing Credibility: Evolving Perceptions of the European Central Bank, NBER Working Paper 11792.

Grüner, Hans Peter (2002) How Much Should Central Banks Talk? A New Argument, Economics Letters 77, 195-198.

Hefeker, Carsten (2003) Federal Monetary Policy, Scandinavian Journal of Economics 105, 643-659.

Hefeker, Carsten (2005) Structural Reforms and the Enlargement of Monetary Union, in P. de Grauwe and J. Mélitz, eds. Prospects for Monetary Union after the Euro, Cambridge: MIT-Press, 31-53.

Hughes Hallett, Andrew and Jan Libich (2006) Central Bank Independence, Accountability and Transparency: Complements or Strategic Substitutes?, CEPR Discussion Paper 5470 .

Jensen, Henrik (2002) Optimal Degree of Transparency in Monetary Policymaking, Scandinavian Journal of Economics 104, 399-422.

Meade, Ellen and Nathan Sheets (2002) Regional Influences on U.S. Monetary Policy: Some Implications for Europe, Board of Governors of the Federal Reserve System, International Finance Discussion Paper 721.

Sibert, Anne and Alan Sutherland (2000) Monetary Regimes and Labour Market Reform, Journal of International Economics 51, 421-435.

Söderström, Ulf (2002) Monetary Policy with Uncertain Parameters, Scandinavian Journal of Economics 104, 125-145.

Sorensen, Jan Rose (1991) Political Uncertainty and Macroeconomic Performance, Economics Letters 37, 377-381.

Ullrich, Katrin (2004) Decision Making of the ECB: Reform and Voting Power, ZEWDiscussion Paper 04-70.

Van der Cruijsen, Carin and Maria Demertzis (2005) The Impact of Central Bank Transparency on Inflation Expectations, De Nederlandsche Bank, mimeo.

Winkler, Bernhard (2000) Which Kind of Transparency: On the Need for Clarity in Monetary Policy Making, ECB Working Paper 26. 


\title{
CESifo Working Paper Series
}

\author{
(for full list see www.cesifo-group.de)
}

1705 Piero Gottardi and Felix Kubler, Social Security and Risk Sharing, April 2006

1706 Giacomo Corneo and Christina M. Fong, What's the Monetary Value of Distributive Justice?, April 2006

1707 Andreas Knabe, Ronnie Schoeb and Joachim Weimann, Marginal Employment Subsidization: A New Concept and a Reappraisal, April 2006

1708 Hans-Werner Sinn, The Pathological Export Boom and the Bazaar Effect - How to Solve the German Puzzle, April 2006

1709 Helge Berger and Stephan Danninger, The Employment Effects of Labor and Product Markets Deregulation and their Implications for Structural Reform, May 2006

1710 Michael Ehrmann and Marcel Fratzscher, Global Financial Transmission of Monetary Policy Shocks, May 2006

1711 Carsten Eckel and Hartmut Egger, Wage Bargaining and Multinational Firms in General Equilibrium, May 2006

1712 Mathias Hoffmann, Proprietary Income, Entrepreneurial Risk, and the Predictability of U.S. Stock Returns, May 2006

1713 Marc-Andreas Muendler and Sascha O. Becker, Margins of Multinational Labor Substitution, May 2006

1714 Surajeet Chakravarty and W. Bentley MacLeod, Construction Contracts (or "How to Get the Right Building at the Right Price?”), May 2006

1715 David Encaoua and Yassine Lefouili, Choosing Intellectual Protection: Imitation, Patent Strength and Licensing, May 2006

1716 Chris van Klaveren, Bernard van Praag and Henriette Maassen van den Brink, Empirical Estimation Results of a Collective Household Time Allocation Model, May 2006

1717 Paul De Grauwe and Agnieszka Markiewicz, Learning to Forecast the Exchange Rate: Two Competing Approaches, May 2006

1718 Sijbren Cnossen, Tobacco Taxation in the European Union, May 2006

1719 Marcel Gérard and Fernando Ruiz, Interjurisdictional Competition for Higher Education and Firms, May 2006 
1720 Ronald McKinnon and Gunther Schnabl, China's Exchange Rate and International Adjustment in Wages, Prices, and Interest Rates: Japan Déjà Vu?, May 2006

1721 Paolo M. Panteghini, The Capital Structure of Multinational Companies under Tax Competition, May 2006

1722 Johannes Becker, Clemens Fuest and Thomas Hemmelgarn, Corporate Tax Reform and Foreign Direct Investment in Germany - Evidence from Firm-Level Data, May 2006

1723 Christian Kleiber, Martin Sexauer and Klaus Waelde, Bequests, Taxation and the Distribution of Wealth in a General Equilibrium Model, May 2006

1724 Axel Dreher and Jan-Egbert Sturm, Do IMF and World Bank Influence Voting in the UN General Assembly?, May 2006

1725 Swapan K. Bhattacharya and Biswa N. Bhattacharyay, Prospects of Regional Cooperation in Trade, Investment and Finance in Asia: An Empirical Analysis on BIMSTEC Countries and Japan, May 2006

1726 Philippe Choné and Laurent Linnemer, Assessing Horizontal Mergers under Uncertain Efficiency Gains, May 2006

1727 Daniel Houser and Thomas Stratmann, Selling Favors in the Lab: Experiments on Campaign Finance Reform, May 2006

1728 E. Maarten Bosker, Steven Brakman, Harry Garretsen and Marc Schramm, A Century of Shocks: The Evolution of the German City Size Distribution 1925 - 1999, May 2006

1729 Clive Bell and Hans Gersbach, Growth and Enduring Epidemic Diseases, May 2006

1730 W. Bentley MacLeod, Reputations, Relationships and the Enforcement of Incomplete Contracts, May 2006

1731 Jan K. Brueckner and Ricardo Flores-Fillol, Airline Schedule Competition: ProductQuality Choice in a Duopoly Model, May 2006

1732 Kerstin Bernoth and Guntram B. Wolff, Fool the Markets? Creative Accounting, Fiscal Transparency and Sovereign Risk Premia, May 2006

1733 Emmanuelle Auriol and Pierre M. Picard, Government Outsourcing: Public Contracting with Private Monopoly, May 2006

1734 Guglielmo Maria Caporale and Luis A. Gil-Alana, Modelling Structural Breaks in the US, UK and Japanese Unemployment Rates, May 2006

1735 Emily J. Blanchard, Reevaluating the Role of Trade Agreements: Does Investment Globalization Make the WTO Obsolete?, May 2006

1736 Per Engström and Bertil Holmlund, Tax Evasion and Self-Employment in a High-Tax Country: Evidence from Sweden, May 2006 
1737 Erkki Koskela and Mikko Puhakka, Cycles and Indeterminacy in Overlapping Generations Economies with Stone-Geary Preferences, May 2006

1738 Saku Aura and Thomas Davidoff, Supply Constraints and Housing Prices, May 2006

1739 Balázs Égert and Ronald MacDonald, Monetary Transmission Mechanism in Transition Economies: Surveying the Surveyable, June 2006

1740 Ben J. Heijdra and Ward E. Romp, Ageing and Growth in the Small Open Economy, June 2006

1741 Robert Fenge and Volker Meier, Subsidies for Wages and Infrastructure: How to Restrain Undesired Immigration, June 2006

1742 Robert S. Chirinko and Debdulal Mallick, The Elasticity of Derived Demand, Factor Substitution and Product Demand: Corrections to Hicks' Formula and Marshall's Four Rules, June 2006

1743 Harry P. Bowen, Haris Munandar and Jean-Marie Viaene, Evidence and Implications of Zipf's Law for Integrated Economies, June 2006

1744 Markku Lanne and Helmut Luetkepohl, Identifying Monetary Policy Shocks via Changes in Volatility, June 2006

1745 Timo Trimborn, Karl-Josef Koch and Thomas M. Steger, Multi-Dimensional Transitional Dynamics: A Simple Numberical Procedure, June 2006

1746 Vivek H. Dehejia and Yiagadeesen Samy, Labor Standards and Economic Integration in the European Union: An Empirical Analysis, June 2006

1747 Carlo Altavilla and Paul De Grauwe, Forecasting and Combining Competing Models of Exchange Rate Determination, June 2006

1748 Olaf Posch and Klaus Waelde, Natural Volatility, Welfare and Taxation, June 2006

1749 Christian Holzner, Volker Meier and Martin Werding, Workfare, Monitoring, and Efficiency Wages, June 2006

1750 Steven Brakman, Harry Garretsen and Charles van Marrewijk, Agglomeration and Aid, June 2006

1751 Robert Fenge and Jakob von Weizsäcker, Mixing Bismarck and Child Pension Systems: An Optimum Taxation Approach, June 2006

1752 Helge Berger and Michael Neugart, Labor Courts, Nomination Bias, and Unemployment in Germany, June 2006

1753 Chris van Klaveren, Bernard van Praag and Henriette Maassen van den Brink, A Collective Household Model of Time Allocation - a Comparison of Native Dutch and Immigrant Households in the Netherlands, June 2006 
1754 Marko Koethenbuerger, Ex-Post Redistribution in a Federation: Implications for Corrective Policy, July 2006

1755 Axel Dreher, Jan-Egbert Sturm and Heinrich Ursprung, The Impact of Globalization on the Composition of Government Expenditures: Evidence from Panel Data, July 2006

1756 Richard Schmidtke, Private Provision of a Complementary Public Good, July 2006

1757 J. Atsu Amegashie, Intentions and Social Interactions, July 2006

1758 Alessandro Balestrino, Tax Avoidance, Endogenous Social Norms, and the Comparison Income Effect, July 2006

1759 Øystein Thøgersen, Intergenerational Risk Sharing by Means of Pay-as-you-go Programs - an Investigation of Alternative Mechanisms, July 2006

1760 Pascalis Raimondos-Møller and Alan D. Woodland, Steepest Ascent Tariff Reforms, July 2006

1761 Ronald MacDonald and Cezary Wojcik, Catching-up, Inflation Differentials and Credit Booms in a Heterogeneous Monetary Union: Some Implications for EMU and new EU Member States, July 2006

1762 Robert Dur, Status-Seeking in Criminal Subcultures and the Double Dividend of ZeroTolerance, July 2006

1763 Christa Hainz, Business Groups in Emerging Markets - Financial Control and Sequential Investment, July 2006

1764 Didier Laussel and Raymond Riezman, Fixed Transport Costs and International Trade, July 2006

1765 Rafael Lalive, How do Extended Benefits Affect Unemployment Duration? A Regression Discontinuity Approach, July 2006

1766 Eric Hillebrand, Gunther Schnabl and Yasemin Ulu, Japanese Foreign Exchange Intervention and the Yen/Dollar Exchange Rate: A Simultaneous Equations Approach Using Realized Volatility, July 2006

1767 Carsten Hefeker, EMU Enlargement, Policy Uncertainty and Economic Reforms, July 2006 